\title{
Dossiê Elites Políticas
}

Privilegiando os estudos de elites políticas, o dossiê deste número da Revista Eletrônica de Ciência Política apresenta quatro artigos de diferentes dimensões teórico/metodológicas que têm em comum a preocupação em focar as elites como objeto de estudo. O positivismo, soberano em grande parte do século passado, defendia que a história, a política ou a sociedade podiam ser explicadas pelo legado dos "grandes homens”. Em oposição a esta ideia, o termo elites, empregado nas diferentes abordagens aqui veiculadas, procura fugir desse determinismo e entender os grupos de elite por uma significação sociológica de sua configuração num contexto social e histórico e compreender suas relações com a estrutura de poder. Essa postura permite, por um lado, evitar a carga moral ou normativa típica do termo e apresentar as vantagens decorrentes do uso desse conceito para a análise da realidade política. Neste sentido, as elites aqui contempladas são definidas posicionalmente e relacionalmente, ora pela detenção de algum poder imbuído por um cargo ocupado, ora pelo fato de serem produtos de uma seleção social. Este tipo de estudo nos possibilita determinar, como bem lembra uma literatura recente dedicada ao estudo das elites, quais os espaços e mecanismos do poder nos diferentes tipos de sociedade e estruturas de poder ou os princípios empregados para o acesso às posições dominantes ${ }^{1}$. Por outro lado, os artigos apresentados têm o interesse de compreender a estrutura de conformação das camadas dirigentes de abaixo para cima, (e não como a maioria dos enfoques dominantes de cima para abaixo) centrando na política e estruturas de poder local.

Com um recorte espaço temporal distinto, os quatro artigos aqui publicados trazem luz ao estudo da política regional. Começando pelas análises cujos balizamentos são mais próximos da política atual, temos o artigo de Tiago Valenciano Previato do Amaral. Em seu artigo As elites políticas de Maringá: um estudo sobre a Câmara Municipal, 1997-2012, sua investigação aponta os padrões de recrutamento, a origem familiar, o perfil sócio-profissional, a escolaridade, a trajetória política e os vínculos políticos, dos vereadores da Câmara Municipal de Maringá, cidade do interior do estado do Paraná. Com um viés de gênero e uma baliza temporal mais perto da política atual, Mulheres e elites locais no Maranhão: perfis, trajetórias e campanhas, o artigo de Dayana dos Santos Delmiro Costa, analisa as formas de acesso das mulheres à elite política maranhense, relacionando o processo de constituições de elites locais e a dinâmica de especialização política. Através da biografia de um ator político importante do período provincial, voltamos ao estudo da

\footnotetext{
${ }^{1}$ HEINZ, F. M.(org.). 2006. Por outra história das elites. Rio de Janeiro: Fundação Getúlio Vargas. 2006, p. 8.
} 
elite paranaense no artigo Biografia, genealogia e teoria das elites: mapeando características do poder local. Escrito por Alessandro Cavassin Alves, este artigo se propõe a fazer uma discussão de pontos importantes na teoria das elites, como a constituição de seus recursos sociais, econômicos e simbólicos em uma determinada localidade e contexto histórico. Nosso último artigo, Recursos Sociais e Seleção Política: chances de ingresso em disputas eleitorais no Rio Grande do Sul entre 1998 e 2006, o autor Rodrigo da Rosa Bordignon, aborda as relações sociais e as diversas modalidades de ingresso na concorrência eleitoral, com o intuito de expor os mecanismos sociais de seleção de candidatos a cargos legislativos e o conjunto de princípios de hierarquização e classificação social que se estendem à concorrência eleitoral.

Para além de contribuir e para continuar despertando o interesse de muitos pesquisadores para um estudo sistemático das elites nas sociedades do passado e do presente, esperamos que este dossiê possa oferecer um panorama do trabalho que vem sendo desenvolvido nesta área. Boa leitura!

Prof. Dr. Miguel Serna (UDELAR)

Editor Docente do Dossiê

Maristela Wessler Dagostim (UFPR)

Camila Tribess (UFPR)

Editoras Discentes do Dossiê 